\title{
Cultural Studies in Dark Times: Public Pedagogy and the Challenge of Neoliberalism
}

\author{
Henry Giroux
}

As the Right wages a frontal assault against all remnants of the democratic state and its welfare provisions, the progressive Left is in disarray. Theoretical and political impoverishment feed off each other as hope of a revolutionary project capable of challenging the existing forces of domination appears remote. Militarism increasingly engulfs the entire social order as matters of "war and national security" become "consuming anxieties" that provide the "memories, models, and metaphors that shape broad areas of national life" as well as drive American foreign policy (Sherry 1995:xi). As U.S. military action expands its reach into Iraq, Afghanistan, and possibly Iran and Syria, under the guise of an unlimited war against terrorism, public spaces on the domestic front are increasingly being organized around values supporting a bellicose, patriarchal, and jingoistic culture that is undermining "centuries of democratic gains" (Buck-Morss 2003:33). As politics is separated from economic power, the state surrenders its obligation to contain the power of corporations and financial capital, reducing its role to matters of surveillance, disciplinary control, and order. Market fundamentalism and the militarization of public life mutually reinforce each other to displace the promise, if not the very idea, of the Great Society-with its emphasis on the common good, basic social provisions for all, social justice, and economic mobility. Fuelled by dreams of empire as well as the desire to mask the shape political power is taking in a period of economic and social decline, militarism and neoliberalism cloak themselves in the discourse of democracy in order to hide the barbarism being reproduced in the torture prisons in Iraq and Afghanistan, in the spread of wage slavery in the interest of capital accumulation, and in the carceral surveillance and disciplinary measures being imposed on the nation's public schools. Democratic political projects appear remote and give rise to either cynicism, solipsism, or reductionistic ideologies on the part of many progressives within and outside of the academy. The crucial task of theorizing a politics suitable for the twenty-first century has fallen on hard times. Economistic theories return to dominate much of the Left, reducing politics to a reflection of economic forces, interests, and measures. Within the university, critically engaged intellectuals appear in short supply as most academics, especially in the humanities and social sciences, bid a hasty retreat to arcane discourses, retrograde notions of professionalism, or irrelevant academic specialities (Agger 1989; Said 2004). Rather than reinventing and rethinking the challenge of an oppositional politics within a global public sphere, the academic Left appears to be withdrawing from the demands of civic engagement by retreating into what Susan Buck-Morss (2003) calls "theory-world," a space where the "academic freedom of critical theorists coincides with our lack of influence in public and political debate"(p. 68). Hope, once embodied in the politics of persuasion, the drive for instituting critical education in a diverse number of public spheres, collective efforts to organize struggles within major institutions, and the attempt to build international social movements seems, at best, a nostalgic remnant of the 1960s. The naturalness and commonsense appeal of the neoliberal economic order produces a crisis of political and historical imagination, on the one hand, and an educational crisis on the other. It is in opposition to the current turn away from matters of history, culture, and politics that I begin with a quote from Susan George, a powerful critic of neoliberalism and a leading voice in the anti-globalization movement. She writes: 
In 1945 or 1950, if you had seriously proposed any of the ideas and policies in today's standard neoliberal toolkit, you would have been laughed off the stage or sent to the insane asylum. At least in the Western countries, at that time, everyone was a Keynesian, a social democrat, or a social Christian democrat or some shade of Marxist. The idea that the market should be allowed to make major social and political decisions, the idea that the state should voluntarily reduce its role in the economy, or that corporations should be given total freedom, that trade unions should be curbed and citizens given much less rather than more social protection-such ideas were utterly foreign to the spirit of the time. Even if someone actually agreed with these ideas, he or she would have hesitated to take such a position in public and would have had a hard time finding an audience (George 1999, para 2).

Times have changed and altered historical conditions posit new problems, define different projects, and often demand fresh discourses. The complex theoretical discourses fashioned in the academy in the 1980s and 1990s seem hopelessly disconnected, if not irrelevant, in the current moment. And the space of democratic political and social thought now appears exhausted by a panoply of military, religious, and market fundamentalisms that refuse to question their own assumptions and instead appeal to the naturalness and inevitability of their ascendancy and the historical struggles that produced it. George's comments are instructive because in resurrecting historical memory, they not only point to a current period in American history in which the seemingly impossible has become possible (Giroux 2004), but also gesture towards those forces that must be named in order to become the object of resistance and refusal. The impossible in this case is the specter of authoritarianism replacing a weakened and damaged liberal democracy. With the election of George W. Bush to the presidency in 2000, the United States finds itself in the midst of a revolution in which the most basic, underlying principles of democracy have begun to unravel. The nature of this right-wing revolution resides in the lived relations of the contemporary social order and the ways in which such relations exacerbate the material conditions of inequality, undercut a sense of individual and social agency, hijack democratic values_-such as egalitarianism and dissent-and promote a deep sense of hopelessness and cynicism. Resuscitating a deeply anti-modernist past as a way to command the future, the Bush administration has evoked the cult of traditionalism, religious fundamentalism, and the absolute reign of the market as central features of an emerging authoritarianism designed to "roll back the twentieth century quite literally"(Greider 2003:11). The alliance of militant neoconservatives, extremist evangelical Christians, and free market fundamentalists imagines a social order modeled on the presidency of William McKinley and the values of the robber barons. The McKinley presidency, which spanned from 1897 to 1901, "had a consummate passion to serve corporate and imperial power" (Moyers 2004). This was an age when blacks, women, immigrants, and minorities of class "knew their place"; big government served the exclusive interests of the corporate monopolists; commanding institutions were under the sway of narrow political interests; welfare was a private enterprise, and labor unions were kept in check by the repressive forces of the state-all while an imperialist war raged in the Philippines. With the geographic shift to Iraq, all of these conditions are being reproduced under the leadership of an extremist element of the Republican Party that holds sway over all branches of government.

One of the central elements of the new authoritarianism is a structural relationship between the state and the economy that produces rigid hierarchies, concentrates power in relatively few hands, unleashes the most brutal elements of a rabid individualism, destroys the welfare state, incarcerates large numbers of its now disposable populations, economically disenfranchises large segments of the lower and middle classes, and reduces entire countries to pauperization (Harvey 2005; Giroux 2003). Neoliberalism not only dissolves the bonds of sociality and reciprocity; it also undermines the nature of social obligations by defining civil society exclusively through an appeal to market-driven values. At the same time neoliberalism feeds a growing authoritarianism steeped in militarism, Christian fundamentalism, and jingoistic patriotism, encouraging intolerance and hate as it punishes critical engagement and questioning, especially if they are at odds with the reactionary religious and political agenda being pushed by the Bush administration.

Increasingly, education appears useful only to those who hold political and economic power, and issues regarding how the academy might contribute to the quality of democratic public life on a national and global level are either ignored or dismissed. On the Right, neoliberal cheerleaders are pushing hard to turn the university into another outpost of corporate learning and training. On the Left, education as a site of dialectical struggle, persuasion, and critical engagement is all too often reduced to ritual debunking and demystification, revealing the political logic of a debased capitalist system. But revelation guarantees nothing and in this case substitutes a limited form of reportage for the hard pedagogical work connecting empowering forms of knowledge to the realities and social forms that bear down on students' everyday lives (Freire 1998). The collective struggle to widen the reach and quality of education as a basis for creating critical citizens - so alive in the sixties - is rendered defunct within the corporate drive for 
efficiency, downsizing, profits, and an utterly instrumentalist notion of excellence. Cornel West (2004) has argued persuasively that just as we need to analyze those dark forces shutting down democracy "we also need to be very clear about the vision that lures us toward hope and the sources of that vision"(p. 18). I want to act on West's utopian call by recapturing the vital role that an expanded notion of critical education might play for educators, students, cultural studies' advocates, and other progressives by providing a language of critique and possibility which addresses the growing threat of free market fundamentalism to an inclusive democracy and the promise of a cultural politics in which pedagogy occupies a formative role in shaping both critical agency and the radical imagination.

But before I make that case, I want to address in more detail neoliberalism as one of the most powerful antidemocratic ideologies now threatening both the idea and formation of a critically informed citizenry, a viable notion of social agency, and the idea of the university as a democratic public sphere. In doing so, I hope to establish a context for analyzing the importance of cultural studies as a theoretical, pedagogical, and political intervention that makes clear both the responsibility of academics to understand and engage neoliberalism within the rising tide of authoritarianism in the United States and elsewhere and what it might mean to offer students and others the hope and tools necessary to revitalize the culture of politics as an ethical response to the demise of democratic public life. At the very least, such a challenge demands that educators and other cultural workers struggle to preserve and revitalize those institutional spaces, forums, and public spheres that support and defend critical education, help students come to terms with their own power as individual and social agents, and reclaim those non-market values such as caring, community, trust, conviction, and courage that are vital to a substantive democracy.

\title{
The Politics of Neoliberalism
}

Neoliberalism not only exerts unparalleled influence on the global economy, but also redefines the very nature of politics and society. Free-market fundamentalism rather than democratic idealism is now the driving force of economics and politics in most of the world. It is a market ideology driven not just by profits but by an ability to reproduce itself with such success that, to paraphrase Fredric Jameson (1994:xii), it is easier to imagine the end of the world than it is to imagine the end of capitalism, even as it creates vast inequalities and promotes human suffering throughout the globe. Wedded to the belief that the market should be the organizing principle for all political, social, and economic decisions, neoliberalism increasingly drives the meaning of citizenship and social life while waging an incessant attack on democracy, public goods, the welfare state, and noncommodified values.

Neoliberal economics has dominated American society since the 1970 s and has been embraced by both New Democrats and conservatives. Both political parties in the U.S. embrace the defining principles of neoliberalism, especially the notions that the market is self-regulating and should be free of interference by the government, that choice is defined as an economic prerogative, and that "economic transactions can subordinate and [in] many cases replace political democracy"(Newfield 2002:314). While there is some political opposition among the established parties to the brutalizing policies of neoliberalism, both political parties generally buy into a corporate driven legislative agenda, which includes:

\begin{abstract}
deregulation of business at all levels of enterprises and trade; tax reduction for wealthy individuals and corporations; the revival of the near-dormant nuclear energy industry; limitations and abrogation of labor's right to organize and bargain collectively; a land policy favoring commercial and industrial development at the expense of conservation and other proenvironment policies; elimination of income support to chronically unemployed; reduced federal aid to education and health; privatization of the main federal pension program, social security; limitations on the right of aggrieved individuals to sue employees and corporations who provide services (Aronowitz 2003:102).
\end{abstract}

Under neoliberalism everything either is for sale or is plundered for profit. One might also add to Aronowitz's list the attack on institutions dedicated to critically informing the public; the handing over by politicians of the public's airwaves over to a handful of powerful broadcasters and large corporate interests without a dime going into the public trust; the attitude toward entire populations, especially those of color who are poor are now considered disposable; the increasing resemblance of schools to either jails or high-end shopping malls, depending on their clientele; the pressure on teachers to get revenue for their school by hawking everything from hamburgers to pizza parties. Additionally, university enrollment and attendance in an era of drastic cutbacks and spiraling tuition becomes once again the near exclusive preserve of the upper middle classes (Giroux and Giroux 2004). 
Corporations more and more not only design the economic sphere but also shape legislation and policy affecting all levels of government, and with limited opposition. As corporate power lays siege to the political process, the benefits flow upward to the rich and the powerful. In Bush's ownership society, government policy now works to benefit the biggest corporations. For example, Bush's 2006 budget contains drastic cuts for many of the major regulatory agencies not only compromising everything from emission standards to drug safety programs, but also presenting the "possibilities—indeed, probability—that these public agencies will become captives of private corporations they are supposed to regulate" (Drutman and Cray 2005:17). It gets worse. Included in such benefits are reform policies that shift the burden of taxes from the rich to the middle class, the working poor, and state governments as can be seen in the shift from taxes on wealth (capital gains, dividends, and estate taxes) to a tax on work, principally in the form of a regressive payroll tax (Collins, Hartman, Kraut, and Mota 2004). During the 20022004 fiscal years, tax cuts delivered $\$ 197.3$ billion in tax breaks to the wealthiest $1 \%$ of Americans (i.e., households making more than $\$ 337,000$ a year) while state governments increased taxes to fill a $\$ 200$ billion budget deficit (Gonsalves 2004). Equally alarming, a recent Congressional study revealed that $63 \%$ of all corporations in 2000 paid no taxes while "[s]ix in ten corporations reported no tax liability for the five years from 1996 through 2000, even though corporate profits were growing at record-breaking levels during that period" (Woodard 2004:para.11).

As neoliberal policies dominate politics and social life, the breathless rhetoric of the global victory of free-market rationality is invoked to cut public expenditures and undermine those non-commodified public spheres that serve as the repository for critical education, public dialogue, and collective intervention. Public services such as health care, child care, public assistance, education, and transportation are now subject to the rules of the market. Social relations between parents and children, doctors and patients, teachers and students are reduced to that of supplier and customer just as the laws of market replace those noncommodified values capable of defending vital public goods and spheres. Forsaking the public good for the private good and hawking the needs of the corporate and private sector as the only source of sound investment, neoliberal ideology produces, legitimates, and exacerbates the existence of persistent poverty, inadequate health care, racial apartheid in the inner cities, and growing inequalities between the rich and the poor (Street 2004; Krugman 2003; Phillips 2003). Under neoliberalism, the state now makes a grim alignment with corporate capital and transnational corporations, legitimating the dangerous presuppositions that corporations should be planning our future and that progress should be defined almost exclusively in economic and technological terms rather than in social and ethical terms. Corporations, in turn, are not designed to be responsible citizens. On the contrary, their sole purpose is to make money and by default accumulate power. Unfortunately, when left unregulated, "they begin to overwhelm the political institutions that can keep them in check, eroding key limitations on their destructive capacities. Internationally, of the 100 largest economies in the world, 51 are corporations and 49 are nations"(Drutman and Cray 2005:17).

In its capacity to dehistoricize and naturalize such sweeping social change, as well as in its aggressive attempts to destroy all of the public spheres necessary for the defense of a genuine democracy, neoliberalism reproduces the conditions for unleashing the most brutalizing forces of capitalism (Derber 2002). Social Darwinism with its ruthless indifference to human suffering has risen like a phoenix from the ashes of nineteenth-century pseudoscience and can now be seen in full display on most reality TV programs and in the unfettered self-interest that now drives popular culture and fits so well with the spirit of authoritarianism. There is no public politics in this discourseonly the private domain of market identities, values, and practices (Giroux 2004). As social bonds are replaced by unadulterated materialism and narcissism, public concerns are now understood and experienced as utterly private miseries, except when offered up on Jerry Springer as fodder for entertainment. Where public space-or its mass mediated simulacrum-does exist, it is the backdrop for a highly orchestrated and sensational confessional for private woes, a cutthroat game of winner-take-all replacing more traditional forms of courtship, as in Who Wants to Marry a Millionaire, or an advertisement for crass consumerism, like MTV's Cribs.

Conscripts in a relentless campaign for personal responsibility, Americans are now convinced that they have little to hope for-and gain from - the government, non-profit public spheres, democratic associations, public and higher education, or other non-governmental social forces. With few exceptions, the project of democratizing public goods has fallen into disrepute in the popular imagination as the logic of the market undermines the most basic social solidarities. The consequences include not only a weakened social state, but a growing sense of insecurity, cynicism, and political retreat on the part of the general public. The incessant calls for self-reliance that now dominate public discourse betray an eviscerated and refigured state that neither provides adequate safety nets for its populace, especially those who are young, poor, or racially marginalized, nor gives any indication that it will serve the interests 
of its citizens in spite of constitutional guarantees.

In fact, the reconfigured state is increasingly becoming a carceral enterprise more concerned with punishing and policing than with nurturing and investing in the public good. Situated within an expanding culture of fear, market freedoms seem securely grounded in a defense of national security, capital, and property rights. When coupled with a media-driven culture of panic and hyped-up levels of insecurity, surviving public spaces are increasingly monitored and militarized. Recently, events in New York, New Jersey, and Washington D.C. provide an interesting case in point. When the media alerted the nation's citizenry to new terrorist threats specific to these areas, CNN ran a lead story on its beneficial impact on tourism - specifically on the enthusiastic clamor by tourist families to get their pictures taken among U.S. paramilitary units now lining city streets, fully flanked with their imposing tanks and massive machine guns. The accouterments of a police state now vie with high-end shopping and museum visits for the public's attention, with only the occasional murmur of protest. But the investment in surveillance and carceral containment is hardly new. Since the early 1990s, state governments have invested more in prison construction than in education, and prison guards and security personnel in public schools are two of the fastest growing professions.

\section{| Neoliberalism as Public Pedagogy}

Within neoliberalism's market-driven discourse, corporate power marks the space of a new kind of public pedagogy, one in which the production, dissemination, and circulation of ideas emerge from the educational force of the larger culture. Public pedagogy in this sense refers to a powerful ensemble of ideological and institutional forces whose aim is to produce competitive, self-interested individuals vying for their own material and ideological gain. Under neoliberalism, pedagogy has become thoroughly reactionary as it operates from a variety of education sites producing forms of pedagogical address in which matters of personal agency, social freedom, and the obligations of citizenship conceive of political and social democracy as a burden, an unfortunate constraint on market relations, profit making, and a consumer democracy (Newfield 2002). Corporate-driven public pedagogy and culture largely cancel out or devalue gender, class-specific, and racial injustices of the existing social order by absorbing the democratic impulses and practices of civil society within narrow economic relations. Knowledge has become capital to invest in the economy but has little to do with the power of self-definition or the capacities needed to expand the scope and operations of freedom and justice. Similarly, corporate public pedagogy has become an all-encompassing cultural horizon for producing not only mega-corporate conglomerates but also market identities, values, and atomizing social practices. As politics increasingly becomes privatized, some neoliberal advocates argue that the answer to solving the health care and education crises faced by many states is to sell off public assets to private interests, just as they insist the problem of social security can be solved through private investment accounts. The Pentagon even considered, if only for a short time, turning the war on terror and security concerns over to futures markets, subject to on-line trading. Neoliberalism utterly privatizes politics and offers absurd solutions to collective problems such as in suggesting that water pollution can be solved by buying bottled water. Thus, non-commodified public spheres are replaced by commercial spheres as the substance of critical democracy is emptied out and replaced by both a democracy of goods available to those with purchasing power and the increasing expansion of the cultural and political power of corporations throughout the world.

Under neoliberalism, dominant public pedagogy with its narrow and imposed schemes of classification and limited modes of identification uses the educational force of the culture to negate the basic conditions for critical agency. What becomes clear in the new information age, or what Zygmunt Bauman (2000) calls liquid modernity, is that the power of the dominant order is not just economic, but ideological—rooted in the ability to mobilize consent, define a particular notion of agency, impose narrow visions of the future, and decouple politics from both social notions of agency and democratic visions of freedom and social justice. Within neoliberal public pedagogy, individuality has nothing to do with self-empowerment. Self-development is instead refashioned as the endless pursuit of personal interests. A belief in the power of a brutalizing self-interest replaces any notion of shared responsibility or social justice. Misfortune in this discourse does not arouse the obligations of citizenship but is relegated to the status of an individual weakness. Public goods are now transformed into sites for individual financial gain and social problems dissolve into the discourse of pathology. Poverty is now viewed as a crime. Racism is viewed as a personal prejudice (more often than not victimizing whites), and unemployment is a mark of weak character. Power, inequality, and social justice disappear from the language of the social, just as the individual increasingly lives 
in a world in which private interests take precedence over social concerns.

As collective agents recede under neoliberalism, market forces incessantly attempt to privatize or commercialize public space. One consequence is that those noncommodified spaces and vernacular capable of providing individuals with the discourses, values, and subject positions crucial to identifying and struggling over institutions vital to the life of democracy begin to disappear from the political scene. Under such circumstances, matters of agency become even more crucial to viable democratic politics as those spaces capable of producing critical modes of pedagogy increasingly slip into the black hole of commercialized space. As public spaces disappear, it becomes more difficult to develop a democratic discourse for educating collective social agents capable of raising critical questions about the limits of a market-driven society as well as what it might mean to theorize about the future of public institutions central to the development of truly substantive democratic society. In the absence of public spaces that promote shared democratic values, a new authoritarian politics and culture emerge in which the state makes a grim alignment with corporate capital, neoconservative visions of empire, and Christian fundamentalism. Political power is now accumulated behind an alliance of economic, political, and religious fundamentalists who recognize that "militarylike discipline abroad requires military-like discipline at home" (Harvey 2003:193). Repressive legislation is used to sacrifice civil liberties in the cause of national security; the government promotes a culture of fear to implement neoliberal policies at home and neoconservative visions of empire abroad; dissent is labeled as unpatriotic, and the media and political parties increasingly become adjuncts of official power (Giroux 2003; Barber 2003; Robin 2004).

As neoliberal economics is accorded more respect than democratic politics, the citizen has been abandoned and the consumer becomes the only viable model of agency. As public spending decreases, education is divorced from democratic politics and the political state increasingly becomes the corporate state (Hertz 2003). All the more reason to take seriously Hannah Arendt's (1965) claim that "without a politically guaranteed public realm, freedom lacks the worldly space to make its appearance" (p.149). And it is precisely within such a realm that subjects are socialized into forms of individual and social agency in which they learn how to govern rather than be governed, to assume the responsibilities of engaged citizens rather than be reduced to consumers or investors. Arendt (1965) understood quite clearly that democracy can only emerge, if not flourish, within political organizations in which education was viewed both as a site of politics and as the foundation that provided the pedagogical conditions in which individuals could learn the knowledge, skills, and values necessary for those forms of citizenship, leadership, and social engagement that deepened and extended the realities of an inclusive democracy. Politics often begins when it becomes possible to make power visible, to challenge the ideological circuitry of hegemonic knowledge, and to recognize that "political subversion presupposes cognitive subversion, a conversion of the vision of the world"(Bourdieu 2001:128). But another element of politics focuses on where politics happens, how proliferating sites of pedagogy bring into being new forms of resistance, raise new questions, and necessitate alternative visions regarding autonomy and the possibility of democracy itself. Neoliberal ideology and pedagogy have been reproduced and reinforced within the advanced countries of the West through the development of new sites of pedagogy and new technologies that penetrate spaces that historically have been beyond the reach of the logic of commercialism and commodification. Hence, it is all the more necessary for educators and other cultural workers to take seriously both the proliferating sites of these new forms of ideological address and the work they do within the social order to create agents and subject positions that become complicitous with the brutalizing logic of the market.

At this point in American history, neoliberal capitalism is not simply too overpowering; on the contrary, "democracy is too weak" (Barber 2002:A23). Profound transformations have taken place in the public space, producing new sites of pedagogy marked by a distinctive confluence of new digital and media technologies, growing concentrations of corporate power, and unparalleled meaning producing capacities. Unlike traditional forms of pedagogy, knowledge and desire are inextricably connected to modes of pedagogical address mediated through unprecedented electronic technologies that include high speed computers, new types of digitized film, and CDROMs. Such sites operate within a wide variety of social institutions and formats including sports and entertainment media, cable television networks, churches, and channels of elite and popular culture, such as advertising. The result is a public pedagogy that plays a decisive role in producing a diverse cultural sphere that gives new meaning to education as a political force.

While John Dewey, Paulo Freire, and various other leading educational theorists in the last century understood the important connection between education and democracy, they had no way in their time of recognizing that the larger culture would extend beyond, if not supercede, institutionalized education, particularly schools, as the most important educational force over developed societies. In fact, education and pedagogy have long been synonymous 
with schooling in the public mind. Challenging such a recognition does not invalidate the importance of formal education to democracy, but it does require a critical understanding of how the work of education takes place in such institutions as well as in a range of other knowledge and meaning producing spheres such as advertising, television, film, the Internet, video game culture, and the popular press. Rather than invalidate the importance of schooling, it extends the sites of pedagogy and in doing so broadens and deepens the meaning and importance of public pedagogy. What is being suggested here is that educators, cultural studies theorists, and others take seriously the role that culture plays, as Raymond Williams (1967:15) puts it, as a form of "permanent education."

The concept of public pedagogy as a form of permanent education underscores the central importance of formal spheres of learning that unlike their popular counterparts—driven largely by commercial interests that more often miseducate the public — must provide citizens with those critical capacities, modes of literacies, knowledge, and skills that enable them to both read the world critically and participate in shaping and governing it. Put differently, formal spheres of learning provide one of the few sites where students can be educated to understand, critically engage, and transform those institutions that are largely shaping their beliefs and sense of agency. I am not claiming that public or higher education are free from corporate influence and dominant ideologies, but that such sites of education, at best, have historically provided the spaces and conditions for prioritizing civic values over commercial interests, for recognizing that consumerism is not the only kind of citizenship, and for vouchsafing the purpose and meaning of critical education in a democratic society that bears its responsibility to present and future generations of young people. In spite of its present embattled status and contradictory roles, higher education, in particular, remains uniquely placed - though also under attack by the forces of corporatization - to prepare students to both understand and influence the larger educational forces that shape their lives. Needless to say, those of us who work in such institutions by virtue of our privileged positions within a rather obvious division of labor have an obligation to draw upon those traditions and resources capable of providing a critical education to all students in order to prepare them for a world in which information and power have taken on new and significant dimensions. In fact, the critique of information cannot be separated from the critique of power itself, providing a substantial new challenge for how we are to theorize politics for the twenty-first century. One way to take up this challenge is to address the theoretical contributions that a number of radical educators and cultural studies theorists have made in engaging not only the primacy of culture as a political force, but also how the relationship between culture and power constitutes a new site of politics, pedagogy, and resistance.

\section{| Cultural Studies and the Question of Pedagogy}

Of course, my position on the civic obligations of the academy is not without its critics. It is not a position that supports traditional views of humanistic education, its canons, or its implicit demand for reverence rather than engagement. Consider, by way of the counter example, Jeffrey Hart (1996), Dartmouth professor and a Senior Editor with the National Review (the right-wing magazine founded by William F. Buckley, a founder of American conservatism and a former employee of the CIA). Echoing the central concerns of the culture wars that conservatives have been waging in full force since the 1980s, his claim is twofold: higher education has been taken over by radicals who are a product of the 1960s, and conservative students are being mistreated because they are overwhelmingly subjected to political indoctrination or harassment. Sounding the alarm on the disciplinary and theoretical advances of the last several decades - like cultural studies and women's studies-Hart responds to the question "How to get a decent college education?" as follows:

Select the ordinary courses. I use ordinary here in a paradoxical and challenging way. An ordinary course is one that has
always been taken and obviously should be taken-even if the student is not yet equipped with a sophisticated rationale
for so doing. The student should be discouraged from putting his money on the cutting edge of interdisciplinary cross-
textuality. If the student should seek out those ordinary courses, then it follows that he should avoid the flashy come-ons.
Avoid things like Nicaraguan Lesbian poets. Yes, and anything listed under 'Studies,' any course whose description uses the
words 'interdisciplinary,' 'hegemonic,' 'phallocratic,' or 'empowerment,' anything that mentions 'keeping a diary,' any course
with a title like 'Adventures in Film.' Also, any male professor who comes to class without a jacket and tie should be regarded
with extreme prejudice unless he has won a Nobel Prize (34).

Unlike Hart who believes that cultural studies is the enemy of not only higher education but also what he would 
term the "disinterested" mind, I believe that cultural studies for all of its diversity and contradictions is one of the few theoretical traditions within the academy that links learning to social change and education to the imperatives of a critical and global democracy.

My own interest in cultural studies emerges out of its early concern with adult education, exemplified in the work of Richard Hoggart (1957), Raymond Williams (1958), Stuart Hall (1992) and Paul Willis (1981), and more recently in the work of Lawrence Grossberg (1997), bell hooks (1994), Stanley Aronowitz (2000), and Nick Couldry (2001), who focus on education more broadly. This tradition, often ignored today, views cultural studies as an empowering practice that "acts directly upon the conditions of culture to change them" (Couldry 2001:66), engages the politics of cultural studies as part of a broader project related to democracy, and views matters of pedagogy as central to the project of cultural studies itself. Within this perspective, intellectual work and practice within the university are articulated as a matter of democracy. Defining the task of cultural studies, Raymond Williams (1989) argued,

it has been about taking the best we can in intellectual work and going with it in this very open way to confront people for whom it is not a way of life, for whom it is not in any probability a job, but for whom it is a matter of their own intellectual interest, their own understanding of the pressures on them, pressures of every kind, from the most personal to the most broadly political-if we are prepared to take that kind of work and revise the syllabus and discipline as best we can...then Cultural Studies has a very remarkable future indeed (161-162).

Such a project calls for intellectual work that is theoretically rigorous, radically contextual, interdisciplinary, and self-critical about its motivating questions and assumptions. This project engages culture through a wide variety of social forms and material relations of power, views theory as a resource, and historical memory as a series of ruptures rather than a totalizing narrative. Cultural studies in this perspective is not only deconstructive, but also willing, to quote Stuart Hall (1992:11), "to address the central, urgent, and disturbing questions of a society and a culture in the most rigorous intellectual way we have available." Such a discourse points to the hard work of providing a language of critique and possibility, of imagining different futures, and addressing the pedagogical conditions that make possible the agents, politics, and forms of resistance necessary to reclaim the promise of a truly global, democratic future.

My commitment to cultural studies emerges out of an ongoing project to theorize the diverse ways in which culture functions as a contested sphere over the production, distribution, and regulation of power and how and where it operates both symbolically and institutionally as an educational, political, and economic force. In this perspective, cultural studies recognizes the primacy of the pedagogical as a critical practice through which politics is pluralized, understood as contingent, and open to many formations. But cultural studies is also crucial for resisting those mutually informing material and symbolic registers in which matters of representation and meaning work to secure particular market identities, legitimate dominant relations of power, and privatize spaces of dialogue and dissent, especially as neoliberalism attempts to undermine the very meaning and practice of a substantive democracy.

Against the neoliberal attack on all things social, cultural studies can play an important role in producing narratives, metaphors, images, and desiring maps that exercise a powerful pedagogical force over how people think about themselves, engage with the claims of others, address questions of justice, and take up the obligations of an engaged citizenship. Within a cultural studies discourse, culture is the primary sphere/space/location in which individuals, groups, and institutions learn to translate the diverse and multiple relations that mediate between private life and public concerns (Bauman 1999). Far from being exclusively about matters of representation and texts, culture becomes a site, event, and performance in which identities and modes of agency are configured through the mutually determined forces of thought and action, body and mind, and time and space. Culture offers a site where common concerns, new solidarities, and public dialogue refigure the fundamental elements of democracy. Culture is also the pedagogical and political ground on which a global public sphere can be imagined to confront the now planetary inequities of symbolic and material power, just as it promotes the possibilities of shared dialogue and democratic transformation. Culture as an emancipatory force affirms the social as a fundamentally political space, just as neoliberalism attempts within the current historical moment to deny culture's relevance as a public sphere and its centrality as a political necessity.

Central to any viable notion of cultural studies, then, is the primacy of culture and power, organized through an understanding of how private issues are connected to larger social conditions and collective forces; that is, how the very processes of learning constitute the political mechanisms through which identities are shaped, desires mobilized, and experiences take on form and meaning within those collective conditions and larger forces that constitute the 
realm of the social. This suggests the necessity on the part of cultural theorists to be particularly attentive to the connections between pedagogy and political agency. Yet, unfortunately, the much needed emphasis on making the political more pedagogical has not occupied a central place in the work of most cultural studies theorists, as it did in the field's earliest formations. Pedagogy in most cultural studies work either is limited to the realm of schooling, dismissed as a discipline with very little academic cultural capital, or is rendered reactionary through the claim that it simply accommodates the paralyzing grip of governmental institutions that normalize all pedagogical practices.

\section{| From a Pedagogy of Understanding to a Pedagogy of Intervention}

In opposition to these positions, I want to reclaim a tradition in radical educational theory and cultural studies in which pedagogy as a critical practice is central to any viable notion of agency, inclusive democracy, and a broader global public sphere. Pedagogy as both a language of critique and possibility looms large in these critical traditions, not as a technique or a priori set of methods, but as a political and moral practice. As a political practice, pedagogy is viewed as the outgrowth of struggles and illuminates the relationships among power, knowledge, and ideology, while self-consciously, if not self-critically, recognizing the role it plays as a deliberate attempt to influence how and what knowledge and identities are produced within particular sets of social relations. As a moral practice, pedagogy recognizes that what cultural workers, artists, activists, media workers, and others teach cannot be abstracted from what it means to invest in public life, presuppose some notion of the future, or locate oneself in a public discourse. The moral implications of pedagogy also suggest that our responsibility as intellectuals for the public cannot be separated from the consequences of the knowledge we produce, the social relations we legitimate, and the ideologies and identities we offer up to students as well as colleagues.

Refusing to decouple politics from pedagogy means, in part, creating those public spaces for engaging students in robust dialogue, challenging them to think critically about received knowledge and energizing them to recognize their own power as individual and social agents. Pedagogy has a relationship to social change in that it should not only help students frame their sense of understanding, imagination, and knowledge within a wider sense of history, politics, and democracy but should also enable them to recognize that they can do something to alleviate human suffering, as the late Susan Sontag (2003) has suggested. Part of this task necessitates that cultural studies theorists and educators anchor their own work, however diverse, in a radical project that seriously engages the promise of an unrealized democracy against its really existing and greviously incomplete forms. Of crucial importance to such a project is rejecting the assumption that theorists can understand social problems without contesting their appearance in public life. More specifically, any viable cultural politics needs a socially committed notion of injustice if we are to take seriously what it means to fight for the idea of the good society. Zygmunt Bauman (2002) is right in arguing that "if there is no room for the idea of wrong society, there is hardly much chance for the idea of good society to be born, let alone make waves" (p. 170).

Cultural studies' theorists need to be more forceful, if not more committed, to linking their overall politics to modes of critique and collective action that address the presupposition that democratic societies are never too just, which means that a democratic society must constantly nurture the possibilities for self-critique, collective agency, and forms of citizenship in which people play a fundamental role in shaping the material relations of power and ideological forces that affect their everyday lives. Within the ongoing process of democratization lies the promise of a society that is open to exchange, questioning, and self-criticism, a democracy that is never finished, and one that opposes neoliberal and neoconservative attempts to supplant the concept of an open society with a fundamentalist market-driven or authoritarian one.

Cultural studies theorists who work in higher education need to make clear that the issue is not whether higher education has become contaminated by politics, as much as recognizing that education is already a space of politics, power, and authority. At the same time, they can make visible their opposition to those approaches to pedagogy that reduce it to a set of skills to enhance one's visibility in the corporate sector or an ideological litmus test that measures one's patriotism or ratings on the rapture index. There is a disquieting refusal in the contemporary academy to raise broader questions about the social, economic, and political forces shaping the very terrain of higher educationparticularly unbridled market forces, fundamentalist groups, and racist and sexist forces that unequally value diverse groups within relations of academic power.

There is also a general misunderstanding of how teacher authority can be used to create the pedagogical 
conditions for critical forms of education without necessarily falling into the trap of simply indoctrinating students. For instance, many conservative and liberal educators believe that any notion of critical pedagogy that is selfconscious about its politics and engages students in ways that offer them the possibility for becoming critical—what Lani Guinier (2003:6) calls the need to educate students "to participate in civic life, and to encourage graduates to give back to the community, which through taxes, made their education possible"-leaves students out of the conversation or presupposes too much or simply represents a form of pedagogical tyranny. While such educators believe in practices that open up the possibility of questioning among students, they often refuse to connect the pedagogical conditions that challenge how and what students think at the moment to the next task of prompting them to imagine changing the world around them so as to expand and deepen its democratic possibilities. Teaching students how to argue, draw on their own experiences, or engage in rigorous dialogue says nothing about why they should engage in these actions in the first place. How the culture of argumentation and questioning relates to giving students the tools they need to fight oppressive forms of power, make the world a more meaningful and just place, and develop a sense of social responsibility is missing in contemporary, progressive frameworks of education.

While no pedagogical intervention should fall to the level of propaganda, a pedagogy which attempts to empower critical citizens can't and shouldn't try to avoid politics. Pedagogy must address the relationships between politics and agency, knowledge and power, subject positions and values, and learning and social change while always being open to debate, resistance, and a culture of questioning. Liberal educators committed to simply raising questions have no language for linking learning to forms of public minded scholarship that would enable students to consider the important relationship between democratic public life and education, or that would encourage students pedagogically to enter the sphere of the political, enabling them to think about how they might participate in a democracy by taking what they learn into new locations and battlegrounds — a fourth grade classroom, a church, the media, a politician's office, the courts, a campus_-or for that matter taking on collaborative projects that address the myriad of problems citizens face on a local, national, and global level in a diminishing democracy.

In spite of the professional pretense to neutrality, academics in the field of cultural studies need to do more pedagogically than simply teach students how to argue and question. Students need much more from their educational experience. Democratic societies need educated citizens who are steeped in more than the skills of argumentation. And it is precisely this democratic project that affirms the critical function of education and refuses to narrow its goals and aspirations to methodological considerations. As Amy Gutmann (1999) argues, education is always political because it is connected to the acquisition of agency, the ability to struggle with ongoing relations of power, and is a precondition for creating informed and critical citizens who act on the world. This is not a notion of education tied to the alleged neutrality of the academy or the new conservative call for "intellectual diversity" but to a vision of pedagogy that is directive and interventionist on the side of producing a substantive democratic society. This is what makes critical pedagogy different from training. And it is precisely the failure to connect learning to its democratic functions and goals that provides rationales for pedagogical approaches that strip critical and democratic possibilities from what it means to be educated.

Cultural studies theorists and educators would do well to take account of the profound transformations taking place in the public sphere and reclaim pedagogy as a central element of cultural politics. In part, this means once again recognizing, as Pierre Bourdieu (2003) has insisted, that the "power of the dominant order is not just economic, but intellectual-lying in the realm of beliefs"(p. 66), and it is precisely within the domain of ideas that a sense of utopian possibility can be restored to the public realm. Such a task suggests that academics and other cultural workers actively resist the ways in which neoliberalism discourages teachers and students from becoming critical intellectuals by turning them into human data banks. Educators and other cultural workers need to build alliances across differences, academic disciplines, and national boundaries as part of broader efforts to develop social movements in defense of the public good and social justice. No small part of this task requires that such groups make visible the connection between the war at home and abroad. If the growing authoritarianism in the U.S. is to be challenged, it is necessary to oppose not only an imperial foreign policy, but also the shameful tax cuts for the rich, the dismantling of the welfare state, the attack on unions, and those policies that sacrifice civil liberties in the cause of national security.

Opposing the authoritarian politics of neoliberalism, militarism, and neoconservatism means developing enclaves of resistance in order to stop the incarceration of a generation of young black and brown men and women, the privatization of the commons, the attack on public schools, the increasing corporatization of higher education, the growing militarization of public life, and the use of power based on the assumption that empire abroad entails tyranny and repression at home. But resistance needs to be more than local or rooted in the specificity 
of particular struggles. Progressives need to develop national and international movements designed to fight the new authoritarianism emerging in the United States and elsewhere. In part, this means revitalizing social movements such as civil rights, labor, environmental, and anti-globalization on the basis of shared values and a moral vision rather than simply issue-based coalitions. This suggests organizing workers, intellectuals, students, youth, and others through a language of critique and possibility in which diverse forms of oppression are addressed through a larger discourse of radical democracy, a discourse that addresses not only what it means to think in terms of a general notion of freedom capable of challenging corporate rule, religious fundamentalism, and the new ideologies of empire, but also what it might mean to link freedom to a shared sense of hope, happiness, community, equality, and social justice. Democracy implies a level of shared beliefs, practices, and a commitment to build a more humane future. Politics in this sense points to a struggle over those social, economic, cultural, and institutional forces that make democracy purposeful for all people. But this fundamentally requires something prior - a reclaiming of the social and cultural basis of a critical education that makes the very struggle over democratic politics meaningful and understandable as part of a broader affective, intellectual, and theoretical investment in public life (Couldry 2004).

As the Bush administration spreads its legacy of war, destruction, commodification, privatization, torture, poverty, and violence across the globe, we need a new language for politics, justice, and freedom in the global public sphere. We need a new vocabulary for talking about what educational institutions should accomplish in a democracy and why they fail; we need a new understanding of public pedagogy for analyzing what kind of notions of agency and structural conditions can bring a meaningful democracy into being. Most important, we need to make pedagogy and hope central to any viable form of politics engaged in the process of creating alternative public spheres and forms of collective resistance. The question of agency cannot be separated from a concern about where democratic struggles can take place and what it might mean to create the affective conditions for students and others to want to engage in such struggles in the first place. Hope, as a precondition for agency, and resistance are crucial elements of democratic politics because not only do they rest on a promise of a better world but they view the future as something more than a repeat of the present. Hope is central to political change and must find a way out of the manufactured cynicism that accompanies current forms of neoliberalism and religious fundamentalism. We need to recognize, as Zygmunt Bauman points out, that the real pessimism is quietism-falsely believing in not doing anything because nothing can be changed (Bunting 2003). Most significantly, we need a new understanding of how culture works as a form of public pedagogy, how pedagogy works as a moral and political practice, how agency is organized through pedagogical relations, how individuals can be educated to make authority responsive, how politics can make the workings of power visible and accountable, and how hope can be reclaimed in dark times through new forms of pedagogical praxis, global protests, and collective resistance.

\section{References}

Agger, Ben. 1989. Fast Capitalism: A Critical Theory of Significance. Urbana: University of Illinois Press.

Arendt, Hannah. 1965. Between Past and Future. New York: Meridian Books.

Aronowitz, Stanley. 2000. The Knowledge Factory. Boston: Beacon Press.

-----. 2003. How Class Works. New Haven: Yale University Press.

Barber, Benjamin R. 2002. "A Failure of Democracy, Not Capitalism.” The New York Times, July 29, p. A23.

-..-.-.. 2003. Fear's Empire: War, Terrorism, and Democracy. New York: Norton.

Bauman, Zygmunt. 1999. In Search of Politics. Stanford: Stanford University Press.

-------. 2000. Liquid Modernity. London: Polity Press.

------. 2002. Society under Siege. Malden, MA: Blackwell.

Bourdieu, Pierre. 2001. Language and Symbolic Power. Cambridge, MA: Harvard University Press.
Bourdieu, Pierre, and Gunter Grass. 2003. "The 'Progressive' Restoration: A Franco-German Dialogue.” New Left Review 14:63-77.

Buck-Morss, Susan. 2004. Thinking Past Terror: Islamism and Critical Theory on the Left. London: Verso.

Bunting, Madeleine. 2003. "Zygmunt Bauman: Passion and Pessimism." The Guardian. http://books.guardian.co.uk/ print/0,3858,4640858 110738,00.html. Accessed April 28, 2005.

Collins, C., C. Hartman, K. Kraut, and G. Mota. 2004, April 20. "Shifty Tax Cuts: How They Move the Tax Burden Off the Rich and onto Everyone Else, United for a Fair Economy." www.FairEconomy.org. Accessed April 24, 2004.

Couldry, Nick. 2001. "Dialogue in an Age of Enclosure: Exploring the Values of Cultural Studies." The Review of Education/Pedagogy/Cultural Studies 23:166.

----. 2004. "In the Place of a Common Culture, What?" The Review of Education/Pedagogy/Cultural Studies 26:1-19. 
Derber, Charles. 2002. People Before Profit. New York: Picador.

Drutman, Lee, and Charlie Cray. 2005. “The People's Business: Controlling Corporations and Restoring Democracy." In These Times, March 14, pp. 16-28.

Freire, Paulo. 1998. Pedagogy of Freedom. Lanham, Md: Rowman and Littlefield.

George, Susan. 2004. "A Short History of Neo-Liberalism: Twenty Years of Elite Economics and Emerging Opportunities for Structural Change". www.globalexchange.org/compaigns/econ101/neoliberal.html. Accessed July 24, 2004.

Giroux, Henry A. 2003. Public Spaces/Private Lives: Democracy Beyond 9/11. Lanham, Md: Rowman and Littlefield.

Giroux, Henry A. 2004. The Terror of Neoliberalism. Boulder, CO: Paradigm.

Giroux, Henry, and Susan Giroux. 2004. Take Back Higher Education: Race, Youth, and the Crisis of Democracy in the Post-Civil Rights Era. New York: Palgrave.

Gonsalves, Steve. 2004. "How to Skin a Rabbit." The Cape Cod Times, www.commondreams.org/views04/0420-05.htm. Accessed April 24, 2004.

Greider, William. 2003. “The Right's Ambition: Rolling Back the 20th Century." The Nation, May 12, pp. 11-19.

Grossberg, Lawrence. 1997. Bringing it all Back Home: Essays on Cultural Studies. Durham: Duke University Press.

Guinier, Lani. 2003 “Democracy Tested.” The Nation, May 5, pp. 6-7.

Gutman, Amy. 1999. Democratic Education. Princeton: Princeton University Press.

Hall, Stuart. 1992. "Race, Culture, and Communications: Looking Backward and Forward at Cultural Studies." Rethinking Marxism 5:10-18.

Hart, Jeffrey. 1996. "How to Get a College Education." The New Republic, September, pp. 34-40.

Harvey, David. 2005. The New Imperialism. New York: Oxford University Press.

Henwood, Doug. 2003. After the New Economy. New York: The New Press.

Hertz, Noreena. 2003. The Silent Takeover: Global Capitalism and the Death of Democracy. New York: Harper Business.
Hoggart, Richard. 1957. The Uses of Literacy. London: Chatto and Windus.

hooks, bell. 1994. Teaching to Transgress. New York: Routledge.

Jameson, Fredric. 1994. The Seeds of Time. New York: Columbia University Press.

Krugman, Paul. 2003. The Great Unraveling: Losing Our Way in the New Century. New York: W.W. Norton.

Moyers, Bill. 2004. "This is Your Story-The Progressive Story of America. Pass It On.” www.utoronto.ca/csus/pm/moyers. htm. Accessed July 20, 2004.

Newfield, Christopher. 2002. "Democratic Passions: Reconstructing Individual Agency." Pp. 314-338 in Materializing Democracy, edited by Russ Castronovo and Dana Nelson. Durham: Duke University Press.

Phillips, Kevin. 2003. Wealth and Democracy: A Political History of the American Rich. New York: Broadway.

Robin, Corey. 2004. Fear: The History of a Political Idea. New York: Oxford.

Said, Edward. 2003. Humanism and Democratic Criticism. New York: Columbia University Press.

Sherry, Michael S. 1995. In the Shadow of War: The United States Since the 1930s. New Haven: Yale University Press.

Sontag, Susan. 2003."Courage and Resistance." The Nation, May 5, pp. 11-14.

Street, Paul. 2004. Empire and Inequality: America and the World Since 9/11. Boulder, CO: Paradigm.

West, Cornel. 2004. "Finding Hope in Dark Times." Tikkun 19:4, pp. 18-20.

Williams, Raymond. 1958. Culture and Society. London: Chatto and Windus. Noble.

-

Willis, Paul. 1981. Learning to Labor. New York: Columbia University Press.

Woodard, Cheryl. 2004, April 15. "Who Really Pays Taxes in America?: Taxes and Politics in 2004." AskQuestions.org. www.askquestions.org/articles/taxes/. Accessed April 20, 2004. 